\title{
In Vitro Bioactivity and Corrosion Properties of Laser Beam Welded Medical Grade AISI 316L Stainless Steel in Simulated Body Fluid
}

\author{
Ceyhun KÖSE ${ }^{1, *}$, Ramazan $K A C ̧ A R^{2}$ \\ ${ }^{1}$ Faculty of Natural Sciences and Engineering, Department of Mechanical Engineering, \\ Gaziosmanpaşa University, Tokat, 60150, Turkey \\ Tel: +90 35625218 00; Fax: +90 3562521729 \\ ${ }^{2}$ Faculty of Technology, Department of Manufacturing Engineering, Karabük University, Karabük, \\ 78050, Turkey, Tel +90 370 4338200/1010; Fax: +90 3704338204 \\ *E-mail: ceyhunia@gmail.com, ceyhun.kose@gop.edu.tr
}

doi: $10.20964 / 110402762$

Received: 6 January 2016 / Accepted: 29 January 2016 / Published: 1 March 2016

\begin{abstract}
AISI 316L stainless steel sheet was joined by $\mathrm{CO}_{2}$ laser beam welding method. In order to determine in vitro bioactivity and corrosion properties of the laser beam welded and non-welded samples were immersed in Simulated Body Fluid (SBF) for 1, 3, 7, 14, 21, 28 days. The bone-like apatite formation was investigated on the surface of the weld area and non-welded samples. Also, corrosion resistance of the laser beam welded and non-welded samples were determined via weight loss method. No corrosion mechanisms were observed in the heat affected zone (HAZ), weld metal of laser beam welded joints, and base material.
\end{abstract}

Keywords: Biomaterials, Surfaces, Welding, Corrosion test.

\section{FULL TEXT}

(C) 2016 The Authors. Published by ESG (www.electrochemsci.org). This article is an open access article distributed under the terms and conditions of the Creative Commons Attribution license (http://creativecommons.org/licenses/by/4.0/). 